\title{
Effect of Anti-Interleukin 12 Treatment on Murine Lyme Borreliosis
}

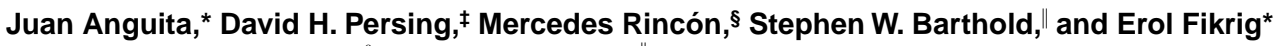

*Sections of Rheumatology, ${ }^{\S}$ Immunobiology and ${ }^{\|}$Comparative Medicine, Yale University School of Medicine, New Haven, Connecticut 06520-8031; and ${ }^{\ddagger}$ Department of Laboratory Medicine and Pathology, Divisions of Clinical Microbiology and Experimental Pathology, Mayo Clinic and Foundation, Rochester, Minnesota 55905

\begin{abstract}
The effect of anti-interleukin (IL)-12 treatment on Lyme borreliosis in $\mathrm{C} 3 \mathrm{H} / \mathrm{HeN}(\mathrm{C} 3 \mathrm{H})$ mice was assessed because other studies have implicated $\mathrm{CD}^{+} \mathrm{T}$ cell helper (Th) type 1 responses in the genesis of disease caused by Borrelia burgdorferi. Infection of inbred mice with $B$. burgdorferi results in varying degrees of arthritis: $\mathrm{BALB} / \mathrm{c}$ mice develop mild disease and $\mathrm{C} 3 \mathrm{H}$ mice develop severe arthritis that is most pronounced $2-4 \mathrm{wk}$ after infection. Since IL-12 is a major inducer of Th1 responses, we blocked this cytokine in vivo in $\mathrm{B}$. burgdorferi infected $\mathrm{C} 3 \mathrm{H}$ mice, and evaluated the effects of treatment on the development of arthritis at the peak of acute joint inflammation (14 d) and in the resolution phase $(60 \mathrm{~d})$ of disease. As expected, intraperitoneal administration of an anti-IL-12 monoclonal antibody (mAb) to $\mathrm{C} 3 \mathrm{H}$ mice resulted in a decrease in both IFN- $\gamma$ and $B$. burgdorferi-specific IgG2a in serum, indicative of diminished Th1 responses. No IL-4 production was detected in serum of anti-IL-12 mAb treated or control mice. IgG1 and IgG2b levels did not increase in $B$. burgdorferi infected mice treated with anti-IL-12 mAb compared with controls suggesting that $\mathrm{Th} 2$ responses were not affected. Nevertheless, $\mathrm{CD}^{+} \mathrm{T}$ cells from both control and anti-IL-12 mAb treated mice had similar in vitro responses to $B$. burgdorferi antigens. Treatment with anti-IL-12 mAb produced a significant reduction in peak arthritis severity, and an increase in the number of spirochetes in ear tissue. These data show that treatment of $B$. burgdorferi infected mice with anti-IL$12 \mathrm{mAb}$ results in a reduction of the Th1 and/or innate immune responses in vivo and a reduction in the severity of acute murine Lyme arthritis. (J. Clin. Invest. 1996. 97:10281034.) Key words: Borrelia burgdorferi • arthritis • cytokines - Th1 response • mice
\end{abstract}

\section{Introduction}

Borrelia burgdorferi is the causative agent of Lyme disease, the most common tick-borne infection in the United States (1). The illness typically begins with a skin lesion (erythema migrans) and may be accompanied by flu-like symptoms (2). Late-stage disease may involve the cardiovascular, nervous and/or musculoskeletal systems $(3,4)$. The pathogenesis of

Address correspondence to Erol Fikrig, M.D., Yale School of Medicine, Section of Rheumatology, P.O. Box 208031, 333 Cedar Street, New Haven, CT 06520-8031. Phone: 203-785-2454; FAX: 203-7857053; E-mail: erol_fikrig@qm.yale.edu

Received for publication 18 August 1995 and accepted in revised form 4 December 1995.

The Journal of Clinical Investigation

Volume 97, Number 4, February 1996, 1028-1034
Lyme arthritis is multifactorial and may be related to the host's major histocompatibility haplotype, humoral and cellular immune responses directed towards B. burgdorferi, and/or spirochetal virulence (5-7). Several studies have correlated the presence of human $\mathrm{CD}^{+} \mathrm{T}$ cell helper (Th1) 1 type responses with the pathogenesis of persistent arthritis (8-10).

Models of murine Lyme borreliosis also suggest that the host immune response can influence the severity of arthritis. Several groups have demonstrated that $\mathrm{BALB} / \mathrm{c}$ mice develop mild arthritis, whereas $\mathrm{C} 3 \mathrm{H} / \mathrm{HeN}(\mathrm{C} 3 \mathrm{H})$ mice develop more severe arthritis $(11,12)$. In both cases, disease is most prominent 14-30 d and resolves 60-90 d after infection (11). All the mice remain persistently infected. Studies involving inbred strains of mice have suggested that disease is more severe in genotypes of mice with high numbers of spirochetes and in mice that develop dominant Th1-like cytokine responses and increased IgG2a production $(13,14)$. In addition, Matyniak and Reiner have correlated the production of IL-4 and IFN- $\gamma$ with resistance and susceptibility, respectively, to the degree of joint swelling in B. burgdorferi infected mice. They also showed that treatment of mice with anti-IL-4 antibodies or anti-IFN- $\gamma$ antibodies can result in modulation of joint swelling (15). $\mathrm{C} 3 \mathrm{H}$ mice (disease-susceptible, with a predominant Th1 response and IFN- $\gamma$ production) treated with anti-IFN- $\gamma$ antibodies developed less severe joint swelling than untreated $\mathrm{C} 3 \mathrm{H}$ mice. Moreover, BALB/c mice (disease-resistant, with a predominant Th2 response and IL-4 production) treated with anti-IL-4 antibodies had more severe joint swelling than their untreated counterparts (15).

IL-12 is a cytokine composed of two subunits (p40 and p35) that is produced by monocyte-macrophages, $\mathrm{B}$ cells, and other accessory cell types (16-18). IL-12 production is enhanced by bacterial and parasite stimulation $(19,20)$, including lipoproteins of B. burgdorferi (21), causes the induction of IFN- $\gamma$ production $(20,22)$, and produces strong Th1-inducing effects (23, 24), as well as augments NK cell cytotoxicity and cytotoxic T cell proliferation and function (16). These characteristics make IL-12 a major modulator of inflammation and immune responses and likely therefore to play a significant role in the pathogenesis of murine Lyme borreliosis. We therefore postulated that blocking the effect of IL-12 - by using anti-IL-12 neutralizing antibodies-would influence Lyme borreliosis in the mouse model. The following study describes the evolution of Lyme borreliosis in $\mathrm{C} 3 \mathrm{H}$ mice treated with a neutralizing anti-IL-12 monoclonal antibody (mAb) and indicates that anti-IL-12 mAb treatment results in a decrease in the severity of acute murine Lyme arthritis.

\section{Methods}

Mice. Six-week-old female $\mathrm{C} 3 \mathrm{H} / \mathrm{HeNCr}$ mice were obtained from the Frederick Cancer Research Center, Frederick, Maryland. Mice were housed in filter frame cages and euthanized with $\mathrm{CO}_{2}$. 
B. burgdorferi. A clonal low passage (third passage) of B. burgdorferi strain $\mathrm{N} 40$ with proven infectivity and pathogenicity in mice was used throughout the studies (25). Spirochetes were grown in Barbour-Stoenner-Kelly (BSK) II medium (26). B. burgdorferi sonicate was prepared using a 7-d culture of B. burgdorferi in BSK II medium. Cells were centrifuged at $10,000 \mathrm{~g}$ and washed three times with phosphate buffered saline (PBS). After the final wash, bacteria were resuspended in $1 \mathrm{ml}$ of PBS and pulsed three times with a cell sonicator for $20 \mathrm{~s}$, with 25 -s intervals.

Infection of mice with B. burgdorferi. Individual mice were challenged with a dose of $10^{4}$ spirochetes administered by intradermal injection in the back, according to our published protocols (27). The studies used groups of 3-5 mice. Two or three different experiments were performed to assess the reproducibility of the results.

Mice were sacrificed at selected time points that represent the stages of peak, severe disease $(14 \mathrm{~d})$ and resolution of disease $(60 \mathrm{~d})$ (28). Mice were assessed for infection by culturing selected organs including the spleen, blood, bladder, and skin (at the inoculation site) (28). To compare the relative number of spirochetes in the spleen and blood of the anti-IL-12 mAb and control mice, three serial (1/10) dilutions were performed on splenic and blood cultures. Cultures were read after $14-\mathrm{d}$ incubations at $33^{\circ} \mathrm{C}$, a time period sufficient for a spirochete to grow to stationary phase.

Pathology. Hearts and joints (both knees and tibiotarsi) were fixed in formalin, embedded in paraffin and blindly examined microscopically for evidence of disease (29). Arthritis severity was scored on a scale of 0 (no disease) to 3 (severe disease) according to our published protocols (29). Grades 1 and 2 represent mild and moderate arthritis, respectively. Active arthritis was scored, tabulated, and distinguished from resolving lesions (no active exudation). Active carditis had aortic and coronary endarteritis, with inflammation of surrounding connective tissue $(25,30)$.

Quantitation of numbers of spirochetes in ear tissue from infected mice by PCR. One whole ear pinna was aseptically collected from each mouse at sacrifice time to minimize both bacterial and DNA contamination (31) and processed using the QIAmp Tissue kit (Qiagen, Chatsworth, CA). Five microliter aliquots of proteasedigested DNA extracts were twofold serially diluted, and each dilution was tested for B. burgdorferi plasmid and chromosomal targets, using $\operatorname{sp} A$ or flagellin gene primers (32). The number of spirochetes per ear from each mouse was estimated on the basis of the most conservative assumptions of a single genome copy per spirochete and single-copy sensitivity of the terminal dilution, as described (33).

Antibody production and in vivo neutralization studies. A mAb against murine IL-12 was produced using the hybridoma C17.8 (provided by G. Trinchieri, Wistar Institute, Philadelphia, PA) in pristane-primed severe combined immunodeficient (scid) mice. The ascitic fluid containing anti-IL-12 $\mathrm{mAb}$ was precipitated with ammonium sulfate at $50 \%$ saturation followed by extensive dialysis and filtration through a $0.45-\mu \mathrm{m}$ filter. The protein content was quantitated and adjusted to $10 \mathrm{mg} / \mathrm{ml}$.

In blocking experiments the $\mathrm{mAb}$ was injected intraperitoneally in the treated group at a dose of $1 \mathrm{mg} / \mathrm{ml}$ in $100 \mu \mathrm{l} 1 \mathrm{~d}$ before infection, on the day of infection and every $4 \mathrm{~d}$ after infection until day 12 , and every $8 \mathrm{~d}$ thereafter (G. Trinchieri, personal communication). The control group was injected in an identical fashion with an irrelevant control antibody (mouse IgG; Sigma Chemical Co., St. Louis, MO).

$T$ cell restimulation assays. Splenic $\mathrm{CD}^{+} \mathrm{T}$ cells were purified by negative selection using mouse anti-IA ${ }^{\mathrm{k}}$ (clone 10-3.6) and rat anti-mouse CD8a (clone 53-6.7) (Pharmingen, San Diego, CA) and goat anti-mouse and goat anti-rat IgG bound to magnetic beads (Perspective Biosystems, Cambridge, MA). Typically, the purity of $\mathrm{CD}^{+} \mathrm{T}$ cells obtained were $>94 \%$, as measured by $\mathrm{FACS}^{\circledR}$ analysis. $10^{6} \mathrm{CD}^{+}$enriched $\mathrm{T}$ cells per well were plated in 24-well plates with cultured B. burgdorferi $\left(10^{6}\right.$ spirochetes $\left./ \mathrm{ml}\right)$ or no stimulus, plus $10^{6}$ cells $/ \mathrm{ml}$ of mitomycin $\mathrm{C}$ treated $(50 \mu \mathrm{g} / \mathrm{ml})$ (ICN Pharmaceuticals, Costa Mesa, CA) syngeneic splenic APCs at a final volume of $1 \mathrm{ml}$.
Supernatants were collected after 20 and $72 \mathrm{~h}$ for IL-4 and IFN- $\gamma$ quantitation, respectively.

Evaluation of cytokine production. The amount of IL-4 and IFN- $\gamma$ present in pooled sera and restimulation supernatants was measured by ELISA using antibodies specific for murine IL-4 and IFN- $\gamma$, respectively, (Pharmingen), following the manufacturer's instructions with some modifications. Briefly, 96-well ELISA plates (ICN) were coated with the capture antibody $(2 \mu \mathrm{g} / \mathrm{ml})$ overnight at $4^{\circ} \mathrm{C}$. After blocking with PBS plus $10 \%$ FCS (PBS/FCS) for $2 \mathrm{~h}$ at room temperature, samples were applied and incubated $1 \mathrm{~h}$ at $37^{\circ} \mathrm{C}$. The biotinylated detection antibody $(1 \mu \mathrm{g} / \mathrm{ml})$ was added after washing the plates with PBS plus Tween $20(0.5 \% \mathrm{vol} / \mathrm{vol})$ (PBS/Tween). Quantitation of cytokine levels was made after incubating the plates with horseradish-conjugated avidin and adding the substrate for the enzyme (TMB; Kirkergaard and Perry Laboratories, Inc., Gaithersburg, MD). Plates were read at $450 \mathrm{~nm}$ after stopping the color developing reaction (TMB 1 Component Stop Solution; Kirkergaard and Perry Laboratories, Inc.). The values indicated are calculated comparing the values obtained with those derived using standard concentrations of recombinant mouse IL- 4 and IFN- $\gamma$ (Pharmingen). The sensitivity of the assays was evaluated to be $<0.5 \mathrm{U} / \mathrm{ml}$ and $1 \mathrm{U} / \mathrm{ml}$ for IL-4 and IFN- $\gamma$, respectively.

B. burgdorferi-specific antibody isotype production. Sera from animals infected with $B$. burgdorferi were used for the quantitation of different antibody isotypes by ELISA using rabbit anti-mouse subclass specific anti-serum to mouse IgG1, IgG2a, and IgG2b (Mouse Typer sub-isotyping panel; Bio-Rad Laboratories, Hercules, CA) as follows. An ELISA plate (ICN) was coated overnight at $4^{\circ} \mathrm{C}$ with 0.5 $\mu \mathrm{g} / \mathrm{ml}$ of B. burgdorferi sonicate in coating buffer (Bicarbonate buffer, $\mathrm{pH}$ 9.6), and blocked for $2 \mathrm{~h}$ at room temperature with PBS plus $10 \%$ FCS. After two washes with PBS/Tween 20 , sera (1/100 or $1 / 500$ dilutions of sera from animals infected for 14 and $60 \mathrm{~d}$, respectively) were applied and incubated $1 \mathrm{~h}$ at room temperature. The wells were washed and the specific antiserum was applied and incubated $1 \mathrm{~h}$ at room temperature. After four washes, HRP-conjugated goat anti-rabbit IgG was applied and incubated $1 \mathrm{~h}$ at room temperature. Quantitation of the different isotypes was carried out after adding peroxidase substrate and reading at $450 \mathrm{~nm}$, as above. Normal (noninfected) mouse serum was used as a control.

FACS analysis. $10^{6}$ cells from single cell suspensions of spleens were stained using phycoerythrin (PE)- or fluoresceinisothiocyanate (FITC)-labeled antibodies against CD4, CD8a and B220 (Pharmingen), for $30 \mathrm{~min}$ at $4^{\circ} \mathrm{C}$. Cell populations were analyzed using a FACS ${ }^{\circledR}$ and the LYSYS program (Becton Dickinson, Franklin Lakes, NJ).

\section{Results}

Treatment with anti-IL-12 mAb causes a decrease in the production of B. burgdorferi-specific IgG2a and IFN- $\gamma$. The functional effect of anti-IL-12 mAb treatment in $\mathrm{C} 3 \mathrm{H}$ mice infected with $B$. burgdorferi was assessed by measuring IFN- $\gamma$, IL-4 and B. burgdorferi-specific IgG1, IgG2a, and IgG2b production in mouse sera compared to sera from infected mice that were not treated with anti-IL-12 mAb. IFN- $\gamma$ and IgG2a were used as two markers for Th1 responses against the spirochete while IL-4 production and IgG1 and IgG2b would reflect $\mathrm{Th} 2$ responses. We first analyzed possible changes in $\mathrm{B}$. burgdorferi-specific antibody isotypes. Sera from infected control mice had significantly greater amounts of $B$. burgdorferi-specific IgG2a than the anti-IL-12 mAb treated group $(P<0.05)$, both at 14 and $60 \mathrm{~d}$ of infection (Table I). When we measured other B. burgdorferi-specific antibody isotypes (IgG1 and IgG2b) no differences were observed between the two groups of mice $(P>0.05)$ (Table I). Since IgG2a has been correlated with the production of IFN- $\gamma$, a cytokine produced during Th1 
Table I. B. burgdorferi-specific Antibodies in Sera of Anti-IL-12 mAb-treated and Control Mice, after 14 and 60 d of Infection

\begin{tabular}{|c|c|c|c|c|}
\hline \multicolumn{2}{|c|}{ Mice } & \multicolumn{3}{|c|}{ Antibody isotype (mean $\mathrm{OD}_{450} \pm \mathrm{STDV}$ ) } \\
\hline Treatment & Day of Death & IgG1 & $\operatorname{IgG} 2 a$ & $\operatorname{IgG} 2 \mathrm{~b}$ \\
\hline Anti-IL-12 mAb & 14 & $0.272 \pm 0.03$ & $0.114 \pm 0.01 *$ & $0.242 \pm 0.03$ \\
\hline Control & 14 & $0.221 \pm 0.05$ & $0.214 \pm 0.04 *$ & $0.213 \pm 0.06$ \\
\hline Anti-IL-12 mAb & 60 & $0.950 \pm 0.15$ & $0.580 \pm 0.01 *$ & $0.744 \pm 0.06$ \\
\hline Control & 60 & $0.745 \pm 0.00^{\ddagger}$ & $0.919 \pm 0.11 *$ & $0.763 \pm 0.09$ \\
\hline Normal mouse serum & & $0.155 \pm 0.01$ & $0.074 \pm 0.01$ & $0.49 \pm 0.02$ \\
\hline
\end{tabular}

Sera were pooled and tested in ELISA plates coated with $0.5 \mu \mathrm{g} / \mathrm{ml}$ of a B. burgdorferi extract. Sera were assessed at dilutions of $1 / 100$ and $1 / 500$ at 14 and $60 \mathrm{~d}$, respectively. Data represent results from 10-16 individual mice in each group. Normal mouse serum was used as a control (1/100 dilution). Statistically significant differences $(P<0.05)$, between treated and control groups are indicated with an asterisk. ${ }^{\ddagger}$ STDV $<0.005$.

responses, we determined IFN- $\gamma$ production by measuring the amount of IFN- $\gamma$ present in the sera of infected animals. The amount of IFN- $\gamma$ present in the sera of the mice treated with anti-IL-12 mAb was lower than in the control group, both at 14 and $60 \mathrm{~d}$ (Fig. 1) and correlated with the decreased production of IgG2a. In addition, no IL-4 production was detected in either group of mice (Fig. 1). These results indicate that antiIL-12 mAb treatment reduced the specific Th1 response against $B$. burgdorferi in vivo.

Anti-IL-12 mAb treatment does not affect $C D 4^{+} T$ cell priming in vivo. To determine if the lack of detectable IL-4 in both treated and untreated mice and the lower production of IFN- $\gamma$ in the anti-IL-12 mAb treated mice could reflect a lack of activation of $\mathrm{CD}^{+} \mathrm{T}$ cells in vivo, we checked the in vitro

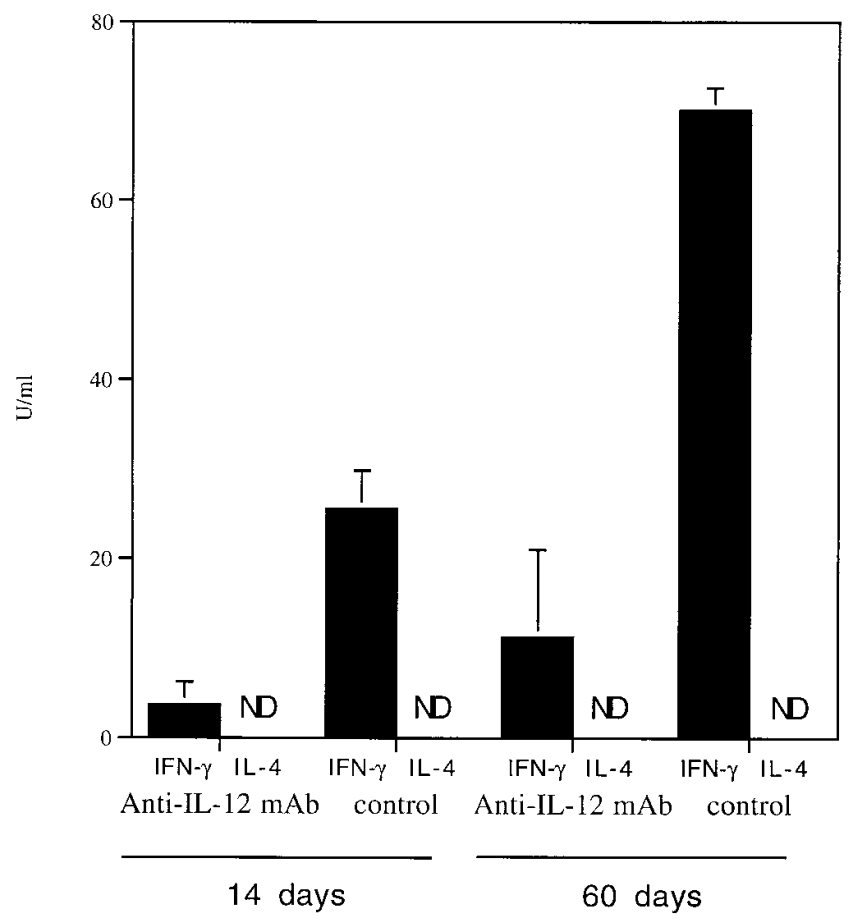

Figure 1. IFN- $\gamma$ and IL-4 detection in the sera of the infected mice. Fourteen and 60 days after infection, sera from anti-IL-12 mAb treated and control mice (10 mice each, in two separate experiments) were collected and pooled, and the levels of IFN- $\gamma(\boldsymbol{\square})$ and IL-4 ( $\square)$ were determined by ELISA. $N D$, not detected. lymphokine response of $\mathrm{CD}^{+} \mathrm{T}$ cells of the infected animals after $14 \mathrm{~d}$ of infection following restimulation with $B$. burgdorferi antigens. No significant differences were detected in the ability of $\mathrm{CD}^{+} \mathrm{T}$ cells to produce in vitro IFN- $\gamma$ in response to B. burgdorferi antigens (Fig. 2). Moreover, as observed in the sera of the mice, no IL-4 production was detected upon specific restimulation (Fig. 2). These data indicate that anti-IL-12 $\mathrm{mAb}$ treatment does not block the differentiation of precursor $\mathrm{CD}^{+}{ }^{+} \mathrm{T}$ cells to effector Th1 cells induced by $B$. burgdorferi and does not favor a Th2 response.

Effects of anti-IL-12 mAb treatment on the course of murine Lyme arthritis. The evolution of murine Lyme arthritis was evaluated in mice treated with anti-IL-12 mAb compared to a control infected group. Fourteen and $60 \mathrm{~d}$ after infection with $10^{4}$ spirochetes, the knees and both tibiotarsi were blindly examined for microscopic evidence of arthritis. An index of the degree of arthritis for each individual mouse was determined by scoring arthritis severity in both tibiotarsal joints

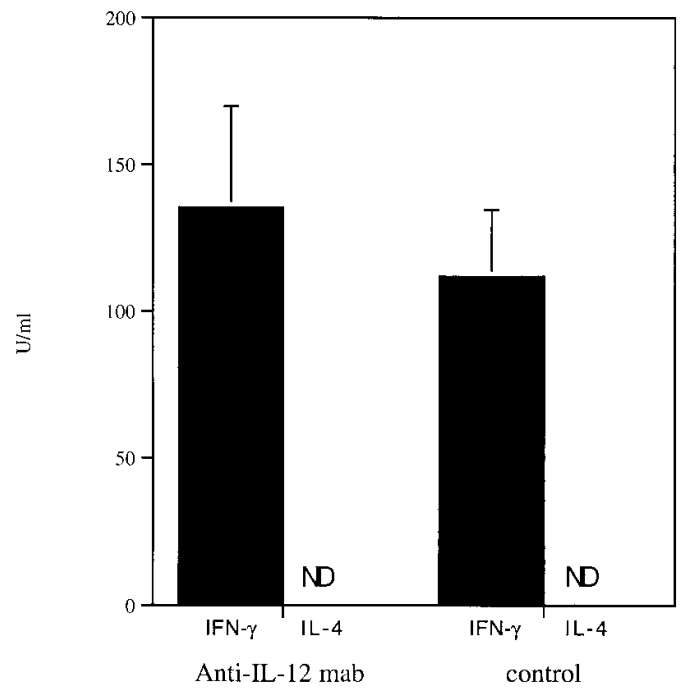

Figure 2. IFN- $\gamma(\mathbf{\square})$ and IL-4 $(\square)$ produced by pooled splenic CD4 ${ }^{+}$ $\mathrm{T}$ cells from anti-IL-12 mAb treated and control mice at $14 \mathrm{~d}$ of infection, restimulated in vitro with $B$. burgdorferi. Splenic $\mathrm{CD}^{+} \mathrm{T}$ cells were purified by negative selection and restimulated $\left(10^{6}\right.$ cells $\left./ \mathrm{ml}\right)$ with cultured B. burgdorferi $\left(10^{6}\right.$ spirochetes $\left./ \mathrm{ml}\right)$, using syngeneic APCs $\left(10^{6} \mathrm{cells} / \mathrm{ml}\right)$. $N D$, not detected. The values represented correspond to a representative experiment from three performed. 
from each mouse, because this is the joint in which arthritis is most consistently discerned (29). Probably due to age of inoculation, arthritis severity was generally mild (Fig. 3), but was significantly less severe $14 \mathrm{~d}$ after challenge in mice treated with anti-IL-12 mAb compared to control mice (Student $t$ test $P<0.05)$. In addition to the decrease in arthritis severity, the number of joints with arthritis was reduced following treatment with anti-IL-12 mAb: $77 \%$ of the knees in the control group had some degree of disease versus $54 \%$ in the treated group, and $38 \%$ versus $13 \%$ of the tibiotarsal joints $(P<0.05)$ (Table II). No differences in carditis were found at this time point (Table II). When the mice were sacrificed at $60 \mathrm{~d}$ no differences in the degree of arthritis were observed between antiIL-12 mAb-treated and control mice (Fig. 2). The number of tibiotarsi with arthritis, however, was lower in the treated group ( 28 vs $40 \%$ in the control group, 5 of 18 and 8 of 20 , respectively, Table II). Carditis was also somewhat less prevalent in anti-IL-12 mAb treated mice than in control animals at $60 \mathrm{~d}$ after infection. All 10 mice in the control group had carditis, whereas 7 of $9(88 \%)$ in the anti-IL-12-treated group had evidence of carditis (Table II). We attempted to correlate the degree of arthritis, as determined by histopathology, with swelling of the tibiotarsus of infected mice, measured in a double blind fashion using calipers. No differences in tibiotarsal swelling (data not shown) were observed between the two groups.

Increase of the number of spirochetes as a result of in vivo blocking of IL-12. To determine whether anti-IL-12 mAb treatment altered the number of spirochetes within infected mice we quantified B. burgdorferi using PCR (32). Quantitative PCR, using ears from the infected animals as an indication of spirochete load, showed that a greater number of spiro-

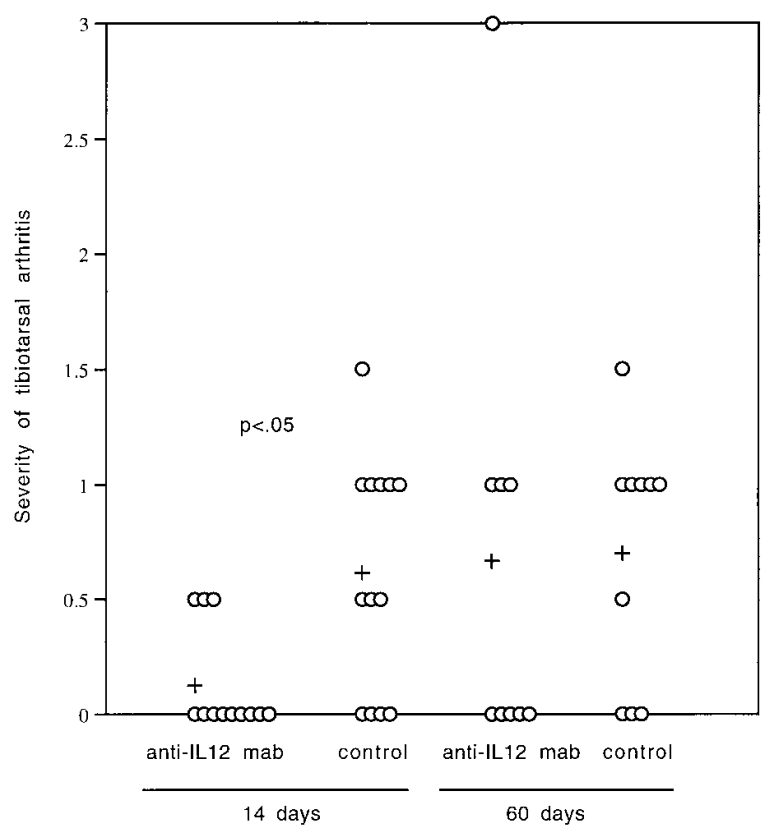

Figure 3. Histopathologic arthritis of the tibiotarsal joints in anti-IL$12 \mathrm{mAb}$ (12 mice) and control mice (13 mice) after 14 and $60 \mathrm{~d}$ of infection. Tibiotarsal joints were fixed in formalin, embedded in paraffin and blindly examined for histopathological signs of arthritis. Each joint was scored in a scale from 0 to 3 , and the values for both hindlegs were added in each mouse (o). The average for each group is also represented $(+)$.
Table II. Arthritis and Carditis in Anti-IL-12 mAb-treated and Control Mice after 14 and $60 \mathrm{~d}$ of Infection with $10^{4} \mathrm{~B}$. burgdorferi $\mathrm{N} 40$

\begin{tabular}{|c|c|c|c|c|}
\hline \multicolumn{2}{|c|}{ Mice } & \multicolumn{3}{|c|}{$\begin{array}{l}\text { Arthritis and carditis } \\
\text { Number of joints } \\
\text { or hearts with disease/number of } \\
\text { joints examined }\end{array}$} \\
\hline Treatment & Day of Death & Knee & Tibiotarsus & Heart \\
\hline Anti-IL-12 mAb & 14 & $13 / 24$ & $3 / 23$ & $11 / 12$ \\
\hline Control & 14 & $20 / 26$ & $10 / 26$ & $13 / 13$ \\
\hline Anti-IL-12 mAb & 60 & $0 / 18$ & $5 / 18$ & $7 / 9$ \\
\hline Control & 60 & $0 / 20$ & $8 / 20$ & $10 / 10$ \\
\hline
\end{tabular}

Hearts and both knee and tibiotarsal joints were examined for arthritis by histopathology of the fixed and embedded tissue.

chetes were present in ears of anti-IL-12 mAb treated mice than in control animals (Fig. 4) at both time points. More spirochetes were present in ears of anti-IL-12 mAb treated or control mice at $14 \mathrm{~d}$ than at $60 \mathrm{~d}$. At $14 \mathrm{~d}$ ears of control mice had an average of $8.6 \times 10^{4}$ spirochetes, whereas ears of antiIL-12 mAb treated mice had $6 \times 10^{5}$. At $60 \mathrm{~d}$, the average number of spirochetes in ears of control mice had decreased to $4.6 \times 10^{3}$, and the number of spirochetes in ears of anti-IL-12 $\mathrm{mAb}$ treated mice had been reduced to $1.3 \times 10^{4}$, a level similar to that found in control mice at $14 \mathrm{~d}$. Furthermore, when blood and spleens were cultured using serial dilutions to compare relative bacterial numbers in both groups, we detected spirochetes at higher dilutions in the spleens of the anti-IL-12 $\mathrm{mAb}$ treated mice after $14 \mathrm{~d}$ of infection (Table III). At $60 \mathrm{~d}, 3$ of 7 spleens from the anti-IL-12 mAb treated mice were culture positive and 1 of 10 mice in the control group had a culture-positive spleen.

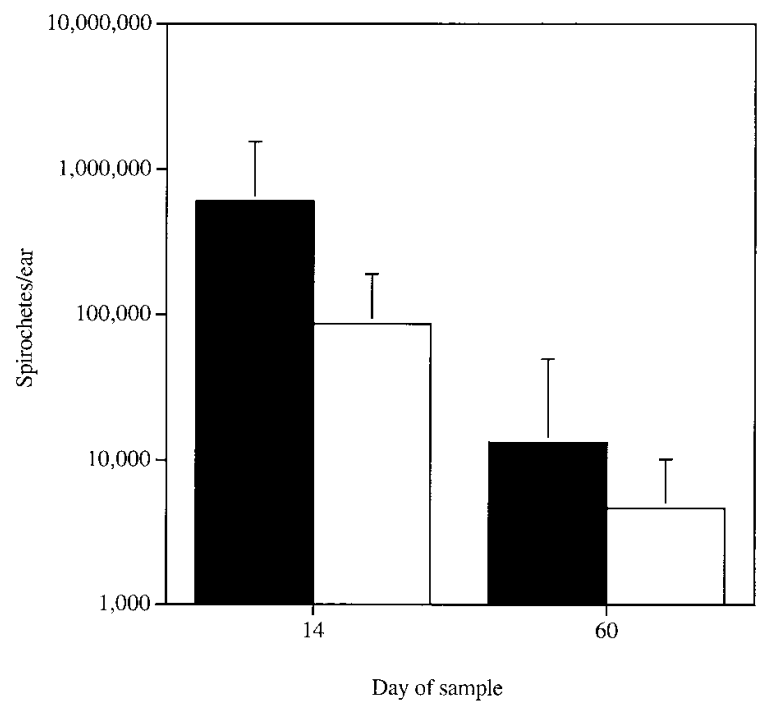

Figure 4. Number of spirochetes in anti-IL-12 mAb (ם) and control mice $(\square)$ measured using quantitative PCR of one ear from individual mice (5-10 mice per group), both at 14 and $60 \mathrm{~d}$ following B. burgdorferi infection. 


\begin{tabular}{|c|c|c|c|c|c|c|c|}
\hline \multicolumn{2}{|c|}{ Mice } & \multicolumn{6}{|c|}{$\begin{array}{l}\text { Isolation of } B \text {. burgdorferi } \\
\text { Number of positive cultures/total number of cultures* }\end{array}$} \\
\hline Treatment & Day of Death & Bladder & Inoc. site & Blood 1 & Blood 2 & Spleen 1 & Spleen 2 \\
\hline Anti-IL-12 mAb & 14 & $10 / 12$ & $12 / 12$ & $7 / 12$ & $1 / 12$ & $6 / 9$ & $5 / 11$ \\
\hline Control & 14 & $13 / 13$ & $13 / 13$ & $7 / 13$ & $2 / 13$ & $5 / 11$ & $1 / 13$ \\
\hline Anti-IL-12 mAb & 60 & $6 / 9$ & $7 / 9$ & $0 / 10$ & $0 / 10$ & $3 / 7$ & $0 / 9$ \\
\hline Control & 60 & $4 / 10$ & $10 / 10$ & $0 / 10$ & $0 / 10$ & $1 / 10$ & $0 / 10$ \\
\hline
\end{tabular}

Blood 1, blood 2, spleen 1, and spleen 2 indicate serial dilutions of these specimens. Cultures were read after $14 \mathrm{~d}$ of incubation of BSK-II medium at $33^{\circ} \mathrm{C}$. Inoc. site represents a specimen of skin $(5 \mathrm{~mm})$ from the site location where $B$. burgdorferi were injected. * Only the cultures that were not contaminated were scored and tabulated.

\section{Discussion}

The analysis of $B$. burgdorferi-infected mice and T cell clones obtained from patients with Lyme disease has suggested that the development of Th1 responses influences the severity of arthritis. Mouse strain-related differences in cytokine and $\mathrm{IgG} 2 \mathrm{a}$ production in response to spirochete infection, reflecting the differential development of $\mathrm{T}$ cell helper responses, suggest a correlation of increased Th1 responses with disease severity $(13,15)$. Moreover, the administration of neutralizing antibodies directed against IFN- $\gamma$ in vivo, mimicking diminished Th1 responses, resulted in a decrease in joint swelling in $\mathrm{C} 3 \mathrm{H}$ mice (15). Therefore, although it may be advantageous to mount Th1 responses to control infections by intracellular pathogens, this strategy is not particularly effective against $B$. burgdorferi, an organism that may be predominantly extracellular. Protection against $B$. burgdorferi infection requires the generation of borreliacidal antibodies directed against certain spirochete antigens, including outer surface protein (Osp) A and $\mathrm{B}(34,35)$, and is therefore influenced by $\mathrm{B}$ cell help provided by $\mathrm{Th} 2$ type $\mathrm{CD} 4^{+} \mathrm{T}$ cells. Thus, the induction of a predominant Th1 response may be a mechanism utilized by the spirochete to reduce, in part, appropriate $\mathrm{T}$ cell responses that can facilitate efficient antibody production and therefore avoid host defenses. Moreover, the maintenance of a Th1 inflammatory response, which leads to destruction of certain tissues where the spirochete resides might be an important source of nutrients.

Our results suggest a role for IL-12 in the expression of arthritis. Anti-IL-12 mAb treatment reduced both the incidence and the severity of acute murine Lyme arthritis in $\mathrm{C} 3 \mathrm{H}$ mice. The reduction in arthritis correlated with a lower level of IFN- $\gamma$ in the sera of the treated animals. Splenic CD $4^{+} \mathrm{T}$ cells from B. burgdorferi infected mice treated with an anti-IL-12 $\mathrm{mAb}$ or a control antibody produced similar amounts of IFN- $\gamma$ when they were restimulated in vitro with $B$. burgdorferi, indicating that the reduced level of IFN- $\gamma$ produced in vivo was not result of lack of $\mathrm{T}$ cell activation.

Murine Lyme arthritis in $\mathrm{C} 3 \mathrm{H}$ mice can be divided into two different phases. Approximately $2-4 \mathrm{wk}$ after infection with $B$. burgdorferi, disease is most severe, with active joint inflammation and carditis. By $60 \mathrm{~d}$, acute inflammation has significantly resolved. Anti-IL-12 mAb treatment produced a significant decrease in arthritis at the peak of the disease (14 d), but had little or no effect at $60 \mathrm{~d}$, the resolution phase of disease. Thus, IL-12 may be involved in the genesis of acute murine Lyme ar- thritis, and the development of a Th1 response may be important in the first stage of the infection. Nevertheless, this response has little effect in the clearance of the bacteria and resolution of the disease because the number of spirochetes in ear tissue of anti-IL-12 mAb treated mice at 14 and $60 \mathrm{~d}$ is greater than in control mice. Moreover, the disease is similar in both groups at $60 \mathrm{~d}$. The reduction in B. burgdorferi-specific antibody production in anti-IL-12 $\mathrm{mAb}$ treated mice may allow the bacterium to persist more efficiently, which explains the higher burden of spirochetes found in the ear tissue of the treated group. This would suggest that the development of arthritis in $\mathrm{C} 3 \mathrm{H}$ mice is dependent in part on the type of cellular immune response against $B$. burgdorferi antigens, and not only on the number of spirochetes in the host. Indeed, anti-IL-12 $\mathrm{mAb}$ treatment decreases the innate immune response, likely including macrophage activation as a result of a lower level of IFN- $\gamma$, and this may contribute, in part, to the reduction in arthritis at the 14-d time point. In contrast, in the late stage of disease, when arthritis is resolving, the treatment with anti-IL$12 \mathrm{mAb}$ does not result in accelerated reduction of arthritis. Other studies have correlated bacterial burden with severity of disease $(13,30,32)$. It is likely that, under normal immune conditions, an increase in the number of spirochetes present in the infected animals produces an increase in the immune response against $B$. burgdorferi, causing an increase in cytokine production and inflammatory responses. In our experiments, in which the response is diminished as a result of the treatment, an increase in the spirochetal burden does not result in increased cytokine production or inflammatory response. It is likely, then, that both factors, the number of spirochetes and the resulting immune response play roles in the pathogenesis of arthritis, and the relative contribution of both factors may differ at various time points in the course of the infection.

In contrast to the arthritis documented by histopathology data, anti-IL-12 mAb treatment did not affect the degree of joint swelling, indicating that gross joint swelling is not indicative of arthritis. Patients with Lyme disease have joint swelling that is disproportionate to the degree of underlying arthritis (36), and it is due to subcutaneous edema. The same is true of mice. They get transient subcutaneous edema, often in the absence of underlying arthritis, or they get arthritis in the absence of subcutaneous edema (gross joint swelling). Thus, the two indices should not be equated to one another. Joint swelling reflects edema and possibly arthritis, but arthritis can only be verified at the microscopic level.

The reduction in IFN- $\gamma$ and $\mathrm{IgG} 2$ a production as a result of 
anti-IL-12 mAb treatment reflects a decrease in the murine Th1 responses in vivo against $B$. burgdorferi. Interestingly, in spite of the Th1 responses produced as a consequence of the treatment, IL-12 neutralization in vivo did not lead to a Th2 response, based on the lack of detection of IL-4 or Th2-mediated $\mathrm{IgG}$ isotypes production in the serum of the treated animals. Nevertheless, the lack of difference in cytokine production by primed $\mathrm{CD}^{+} \mathrm{T}$ cells after in vitro restimulation with B. burgdorferi suggests that the differentiation to a Th1 phenotype in both groups of mice was equivalent. Some reports have indicated that the presence of IL-12 is required for the development of Th1 responses $(37,38)$, while other studies suggest that both IL-12 and IFN- $\gamma$ are required (39). Moreover, mouse strain-specific backgrounds can directly influence Th1 development under neutral conditions (40). The disparity observed in terms of IFN- $\gamma$ production in vitro and in vivo in the antiIL-12 mAb treated group of mice could be a consequence of the lower amount of IL-12 in vivo in the treated group, causing a decrease in $\mathrm{CD}^{+} \mathrm{T}$ cell responses $(41,42)$, while in vitro the APCs used can produce appreciable amounts of IL-12 in response to B. burgdorferi that could serve as a costimulatory signal (21). The lower levels of IFN- $\gamma$ in the sera of the treated mice may also be a consequence of the lack of activation of other cell types that can produce this cytokine, such as NK cells or $\gamma \delta$ T cells (43). These cells could be less activated in the anti-IL-12 mAb treated group, even though TNF- $\alpha$ produced in response to $B$. burgdorferi lipoproteins $(21,44)$ can produce NK cell activation (45) and the proposed presence of a superantigen-like activity in $B$. burgdorferi (46) could cause IFN- $\gamma$ production by some cell types (47).

In conclusion, treatment with anti-IL-12 mAb during $B$. burgdorferi infection in $\mathrm{C} 3 \mathrm{H}$ mice results in a decrease in the severity of acute arthritis, suggesting that a decrease in the Th1 and/or innate cellular inflammatory responses are associated with a reduction in Lyme disease in the early stage of murine infection. Even though murine and human Lyme borreliosis cannot be considered as equivalent, the murine model has provided insights into the immune response to B. burgdorferi that has helped lead to the development of an experimental human OspA based vaccine. The finding that the treatment with antiIL-12 decreases the Th1 responses in vivo and consequently the degree of acute disease, indicates that the development of this type of $\mathrm{T}$ cell response is responsible for some of the arthritis that results from spirochetal infection. Th1 responses are produced during human Lyme disease $(9,10)$, suggesting a correlation between the development of Th1 responses against B. burgdorferi and the severity of human Lyme disease. Our results would indicate that immune responses that can be blocked by anti-IL-12 contribute to the pathogenesis of acute murine Lyme arthritis. It is likely, therefore, that B. burgdorferi specific Th1 responses influence the evolution of murine and human Lyme borreliosis.

\section{Acknowledgments}

We thank Richard A. Flavell, Sylvie Guerder, Basel K. Al Ramadi and Rita Roth for helpful discussions, and Deborah Beck, Rhonda Bangham, Maria Wycocka, and Barbara J. Rutledge for technical assistance. We also thank G. Trinchieri for generously providing the anti-IL-12 mAb used in this study.

This work was supported by grants from the National Institutes of Health AR-40452, AI-30548, AI-49387, AI-26815, AI-32403, AR-
41497, Centers for Disease Control and Prevention (U5-CCU106581, CCU-510343-02), Mathers and Arthritis Foundations, American Heart Association, and the State of Connecticut (Goodyear Award). Erol Fikrig is a Pew Scholar.

\section{References}

1. Malawista, S.E. 1992. Lyme disease. In Cecil's Textbook of Medicine. 19th ed. W.B. Saunders, editor, Philadelphia, PA. 1772-1777.

2. Steere, A.C., N.H. Bartenhagen, J.E. Craft, G.J. Hutchinson, J.H. Newman, D.W. Rahn, L.H. Sigal, P.H. Spieler, K.S. Stenn, and S.E. Malawista. 1983. The early clinical manifestations of Lyme disease. Ann. Intern. Med. 99: $76-82$.

3. Steere, A.C., W.P. Batsford, M. Weinberg, J. Alexander, H.J. Berger, S Wolfson, and S.E. Malawista. 1980. Lyme carditis: cardiac abnormalities of Lyme disease. Ann. Intern. Med. 93:8-16.

4. Steere, A.C., A. Gibofsky, M.E. Patarroyo, R.J. Winchester, J.A. Hardin, and S.E. Malawista. 1979. Chronic Lyme arthritis: clinical and immunogenic differentiation from rheumatoid arthritis. Ann. Intern. Med. 90:286-291.

5. Anderson, J.F., S.W. Barthold, and L.A. Magnarelli. 1990. Infectious but non pathogenic isolate of Borrelia burgdorferi. J. Clin. Microbiol. 28:2693-2699.

6. Kalish, R.A., J.M. Leong, and A.C. Steere. 1993. Association of treatment-resistant chronic Lyme arthritis with HLA-DR4 and antibody reactivity to OspA and OspB of Borrelia burgdorferi. Infect. Immun. 61:2774-2779.

7. Steere, A.C., E. Dwyer, and R. Winchester. 1990. Association of chronic Lyme arthritis with HLA-DR4 and HLA-DR2 alleles. N. Engl. J. Med. 323 219-223.

8. Shanafelt, M.C., J. Anzola, C. Soderberg, H. Yssel, C.W. Turck, and G. Peltz. 1992. Epitopes on the outer surface protein A of Borrelia burgdorferi recognized by antibodies and $\mathrm{T}$ cells of patients with Lyme disease. J. Immunol. 148:218-224.

9. Yssel, H., T. Nakamoto, P. Schneider, V. Freitas, C. Collins, D. Webb, N Mensi, C. Soderberg, and G. Peltz. 1990. Analysis of T lymphocytes cloned from the synovial fluid and blood of a patient with Lyme arthritis. Int. Immunol. 2:1081-1089.

10. Yssel, H., M. Shanafelt, C. Soderberg, P.V. Schneider, J. Anzola, and G. Peltz. 1991. Borrelia burgdorferi activates a T helper type 1-like T cell subset in Lyme Arthritis. J. Exp. Med. 174:593-601.

11. Barthold, S.W., D.S. Beck, G.M. Hansen, G.A. Terwilliger, and D. Moody. 1990. Lyme borreliosis in selected strains and ages of laboratory mice. J. Infect. Dis. 162:133-138.

12. Schaible, U.E., M.D. Kramer, R. Wallich, T. Tran, and M.M. Simon. 1991. Experimental Borrelia burgdorferi infection in inbred mouse strains: antibody response and association of $\mathrm{H}-2$ genes with resistance and susceptibility to development of arthritis. Eur. J. Immunol. 21:2397-2405.

13. Yang, L., J.H. Weis, E. Eichwald, C.P. Kolbert, D.H. Persing, and J.J. Weis. 1994. Heritable susceptibility to severe Borrelia burgdorferi-induced arthritis is dominant and is associated with persistence of large numbers of spirochetes in tissues. Infect. Immun. 62:492-500.

14. Yang, L., Y. Ma, R. Schoenfeld, M. Griffiths, E. Eichwald, B. Araneo, and J.J. Weis. 1992. Evidence for B-lymphocyte mitogen activity in Borrelia burgdorferi-infected mice. Infect. Immun. 60:3033-3041.

15. Matyniak, J.E., and S.L. Reiner. 1995. T helper phenotype and susceptibility in experimental Lyme disease. J. Exp. Med. 181:1251-1254.

16. Brunda, M.J. 1994. Interleukin-12. J. Leukocyte Biol. 55:280-288.

17. Kobayashi, M., L. Fitz, M. Ryan, R.M. Hewick, S.C. Clark, S. Chan, R. Loudon, F. Sherman, B. Perussia, and G. Trinchieri. 1989. Identification and purification of natural killer cell stimulatory factor (NKSF), a cytokine with multiple biological effects on human lymphocytes. J. Exp. Med. 170:827-845.

18. Stern, A.S., F.J. Podlaski, J.D. Hulmes, Y.E. Pan, P.M. Quinn, A.G. Wolitzky, P.C. Familletti, D.L. Stremlo, T. Truitt, R. Chizzonite, and M.K. Gately. 1990. Purification to homogeneity and partial characterization of cytotoxic lymphocyte maturation factor from human B-lymphoblastoid cells. Proc. Natl. Acad. Sci. USA. 87:6808-6812.

19. Vieira, L.Q., B.D. Hondowicz, L.C. Afonso, M. Wysocka, G. Trinchieri, and P. Scott. 1994. Infection with Leishmania major induces interleukin-12 production in vivo. Immunol. Lett. 40:157-161.

20. Gazzinelli, R.T., M. Wysocka, S. Hayashi, E.Y. Denkers, S. Hieny, P. Caspar, G. Trinchieri, and A. Sher. 1994. Parasite-induced IL-12 stimulates early IFN- $\gamma$ synthesis and resistance during acute infection with Toxoplasma gondii. J. Immunol. 153:2533-2543.

21. Radolf, J.D., L.L. Arndt, D.R. Akins, L.L. Curetty, M.E. Levi, Y. Shen, L.S. Davis, and M.V. Norgard. 1995. Treponema pallidum and Borrelia burgdorferi lipoproteins and synthetic lipopeptides activate monocytes/macrophages. J. Immunol. 154:2866-2877.

22. Chang, S.H., M. Kobayashi, D. Santoli, B. Perussia, and G. Trinchieri. 1992. Mechanisms of IFN- $\gamma$ induction by natural killer cell stimulatory factor (NKSF/IL-12): role of transcription and mRNA stability in the synergistic interaction between NKSF and IL-2. J. Immunol. 148:92-98.

23. Manetti, R., P. Parronchi, M.G. Guidizi, M.P. Piccini, E. Maggi, G. Trinchieri, and S. Romagnani. 1993. Natural killer cell stimulatory factor inter- 
leukin 12 (IL-12) induces T helper type 1 (Th1)-specific immune responses and inhibits the development of IL-4 producing Th cells. J. Exp. Med. 177:1199-1204.

24. Trinchieri, G. 1993. Interleukin-12 and its role in the generation of Th1 cells. Immunol. Today. 14:335-338.

25. Barthold, S.W., M.S. de Souza, J.L. Janotka, A.L. Smith, and D.H. Persing. 1993. Chronic Lyme borreliosis in the laboratory mouse. Am. J. Pathol. 143:959-971.

26. Barbour, A.G. 1984. Isolation and cultivation of Lyme disease spirochetes. Yale J. Biol. Med. 57:521-525.

27. Fikrig, E., H. Tao, F.S. Kantor, S.W. Barthold, and R.A. Flavell. 1993. Evasion of protective immunity by Borrelia burgdorferi by truncation of outer surface protein B. Proc. Natl. Acad. Sci. USA. 90:4092-4096.

28. Fikrig, E., S.W. Barthold, F.S. Kantor, and R.A. Flavell. 1992. Long term protection of mice from Lyme disease by immunizing with recombinant OspA. Infect. Immun. 60:773-778.

29. Fikrig, E., S.W. Barthold, and R.A. Flavell. 1993. OspA vaccination of mice with established Borrelia burgdorferi infection alters disease but not infection. Infect. Immun. 61:2553-2558.

30. Barthold, S.W., D.H. Persing, A.L. Armstrong, and R.A. Peeples. 1991. Kinetics of Borrelia burgdorferi: dissemination and evolution of disease following intradermal inoculation of mice. Am. J. Pathol. 163:263-273.

31. Malawista, S.E., S.W. Barthold, and D.H. Persing. 1994. Fate of Borrelia burgdorferi DNA in tissues of infected mice after antibiotic treatment. J. Infect. Dis. 170:1312-1316.

32. Persing, D.H., B.J. Rutledge, P.N. Rys, D.S. Podzorski, P.D. Mitchell, K.D. Reed, B. Liu, E. Fikrig, and S.E. Malawista. 1994. Target imbalance: disparity of Borrelia burgdorferi genetic material in synovial fluid from Lyme arthritis patients. J. Infect. Dis. 169:668-672.

33. Barthold, S.W., E. Fikrig, L.K. Bockendtedt, and D.H. Persing. 1995. Circumvention of outer surface protein A immunity by host-adapted Borrelia burgdorferi. Infect. Immun. 63:2255-2261.

34. Fikrig, E., S.W. Barthold, F.S. Kantor, and R.A. Flavell. 1990. Protection of mice against the Lyme disease agent by immunizing with recombinant OspA. Science (Wash. DC). 250:553-556.

35. Fikrig, E., S.W. Barthold, N. Marcantonio, K. Deponte, F.S. Kantor, and R.A. Flavell. 1992. Roles of OspA, OspB, and flagellin in protective immunity to Lyme borreliosis in laboratory mice. Infect. Immun. 59:553-559.

36. Steere, A.C. 1989. Lyme disease. N. Engl. J. Med. 9:586-596.

37. Romani, L., A. Mencacci, L. Tonnetti, R. Spaccapelo, E. Cenci, S. Wolf, P. Puccetti, and F. Bistoni. 1994. Interleukin-12 but not IFN- $\gamma$ production cor- relates with induction of T helper type-1 phenotype in murine candidiasis. Eur. J. Immunol. 24:909-915.

38. Romani, L., A. Mencacci, L. Tonnetti, R. Spaccapelo, E. Cenci, P. Puccetti, S.F. Wolf, and F. Bistoni. 1994. IL-12 is both required and prognostic in vivo for $\mathrm{T}$ helper type 1 differentiation in murine candidiasis. J. Immunol. 153 $5167-5175$.

39. Schmitt, E., P. Hoehn, C. Huels, S. Goedert, N. Palm, E. Rude, and T. Germann. 1994. T helper type 1 development of naive $\mathrm{CD}^{+} \mathrm{T}$ cells requires the coordinate action of interleukin-12 and IFN- $\gamma$ and is inhibited by transforming growth factor $\beta$. Eur. J. Immunol. 24:793-798.

40. Hsieh, C., S.E. Macatonia, A. O'garra, and K.M. Murphy. 1995. T cell helper background determines default $\mathrm{T}$ helper phenotype development in vitro. J. Exp. Med. 181:713-721.

41. Kubin, M., M. Kamoun, and G. Trinchieri. 1994. Interleukin 12 synergizes with $\mathrm{B} 7 / \mathrm{CD} 28$ interaction in inducing efficient proliferation and cytokine production of human T cells. J. Exp. Med. 180:211-222.

42. Murphy, E.E., G. Terres, S.E. Macatonia, C. Hsieh, J. Mattson, L. Lanier, M. Wysocka, G. Trinchieri, K. Murphy, and A. O'Garra. 1994. B7 and interleukin 12 cooperate for proliferation and IFN- $\gamma$ production by mouse $\mathrm{T}$ helper clones that are unresponsive to B7 costimulation. J. Exp. Med. 180:223231.

43. Skeen, M.J., and H.K. Ziegler. 1995. Activation of $\gamma \delta$ T cells for production of IFN- $\gamma$ is mediated by bacteria via macrophage-derived cytokines IL-1 and IL-12. J. Immunol. 154:5832-5841.

44. Radolf, J.D., M.V. Norgard, M.E. Brandt, R.D. Isaacs, P.A. Thompson, and B. Beutler. 1991. Lipoproteins of Borrelia burgdorferi and Treponema pallidum activate cachectin/tumor necrosis factor synthesis. Analysis using a CAT reporter construct. J. Immunol. 147:1968-1974.

45. Hunter, C.A., C.S. Subauste, V.H. Van Cleave, and J.S. Remington. 1994. Production of gamma interferon by natural killer cells from Toxoplasma gondii-infected SCID mice: regulation by interleukin-10, interleukin-12, and tumor necrosis factor alpha. Infect. Immun. 62:2818-2824.

46. Lahesmaa, R., M.C. Shanafelt, A. Allsup, C. Soderberg, J. Anzola, V. Freitas, C. Turck, L. Steinman, and G. Peltz. 1993. Preferential usage of T cel antigen receptor $\mathrm{V}$ region gene segment $\mathrm{V} \beta 5.1$ by Borrelia burgdorferi antigen-reactive $\mathrm{T}$ cell clones isolated from a patient with Lyme disease. J. Immunol. 150:4125-4135.

47. D’Orazio, J.A., G.W. Burke, and J. Streilein. 1995. Staphylococcal enterotoxin B activates purified NK cells to secrete IFN- $\gamma$ but requires T lymphocytes to augment NK cytotoxicity. J. Immunol. 154:1014-1023. 